\title{
Analisis Efektivitas Sosialisasi Perpajakan dan Pengetahuan Perpajakan dalam Rangka Meningkatkan Kepatuhan Wajib Pajak pada KPP Madya Sidoarjo
}

\author{
*Nur Lailiyatul Inayah, Kusni Hidayati, Nabila Almas Brillianty A. \\ Prodi Manajemen Fakultas Ekonomi dan Bisnis \\ Universitas Bhayangkara Surabaya, Indonesia
}

DOI: 10.46821/ekobis.v2i1.207

\begin{abstract}
ABSTRAK
Hasil penelitian ini menunjukkan bahwa efektivitas sosialisasi perpajakan dan pengetahuan perpajakan berpengaruh efektif dalam rangka meningkatkan kepatuhan Wajib Pajak. Sosialisasi perpajakan yang dilaksanakan oleh KPP Madya Sidoarjo menunjukkan pengaruh efektif untuk meningkatkan pengetahuan Wajib Pajak dapat menambah pengetahuan dasar pajak serta meningkat kepatuhan dalam diri Wajib Pajak terhadap peraturan pajak yang ditetapkan KPP Madya Sidoarjo. Kepatuhan Wajib Pajak dapat dilihat dari seberapa patuh Wajib Pajak saat menyampaikan SPT.
\end{abstract}

Kata Kunci: Sosialisasi, Pengetahuan, Kepatuhan Wajib Pajak

\section{ABSTRACT}

This research results show that the effectiveness of tax socialization and tax knowledge have an effective effect in order to increase tax compliance. Tax socialization carried out by the KPP Madya Sidoarjo showed an effective effect on increasing taxpayer knowledge, increasing tax basic knowledge and increasing taxpayer compliance with tax regulations set by the KPP Madya Sidoarjo. The duty of the tax-payer can be seen from how much duty the tax-payer pays when he delivers the notice.

Keywords : Socialization, Knowledge, Tax Compliance

\section{PENDAHULUAN}

Pembangunan nasional merupakan kegiatan berkelanjutan untuk meningkatkan kesejahteraan rakyat. Untuk mencapai tujuan tersebut, diperlukan perhatian yang besar pada masalah-masalah dalam pembiayaan bangunan di Indonesia, karena lebih dari $80 \%$ penerimaan negara berasal dari pajak. Pemerintah mengungkapkan bahwa penerimaan perpajakan dipengaruhi oleh aktivitas ekonomi domestik dan kinerja perdagangan internasional (impor). Selain itu, Pemerintah juga mengungkapkan bahwa dalam 3 tahun terakhir penerimaan pajak dipengaruhi oleh berbagai kebijakan perpajakan yang berdampak secara signifikan terhadap penerimaan pajak. Dalam artikel yang ditulis oleh Santoso (2019) menyebutkan bahwa Menurut Kementerian Keuangan Republik Indonesia, Sri Mulyani, menyampaikan bahwa penyebab belum dapat tercapainya target penerimaan pajak di Indonesia salah satunya adalah karena tingkat kepatuhan Wajib Pajak yang masih kurang. 
Menurut (Rahayu, 2017), Kepatuhan Wajib Pajak merupakan tujuan utama dari pemeriksaan pajak, sehingga dari hasil pemeriksaan akan diketahui tingkat kepatuhan Wajib Pajak. Dalam wawancara, Mardiasmo (2019) Wakil Menteri Keuangan mengungkapkan empat strategi yang bisa dilakukan otoritas pajak untuk meningkatkan Kepatuhan Wajib Pajak dalam melaksanakan pembayaran pajak. Salah satunya adalah melakukan kegiatan sosialisasi maupun edukasi secara berkelanjutan untuk meningkatkan kesadaran atas pentingnya membayar pajak.

Tidak hanya sosialisasi perpajakan, ada salah satu faktor penting agar kepatuhan wajib pajak meningkat yaitu pengetahuan perpajakan. Pengetahuan serta pemahaman tentang peraturan perpajakan adalah proses dimana Wajib Pajak memahami perpajakan dan menerapkan dalam perpajakan.

\section{TINJAUAN PUSTAKA}

\section{Sosialisasi Perpajakan}

Sosialisasi perpajakan adalah salah satu upaya Direktorat Jenderal Pajak untuk memberikan pemahaman, informasi, dan edukasi kepada masyarakat secara umum, terutama segala hal tentang Wajib Pajak terkait dengan Undang-Undang dan peraturan perpajakan. Dengan adanya sosialisasi perpajakan yang dilakukan oleh Direktorat Jenderal Pajak bisa meningkatkan kesadaran masyarakat dan kesadaran Wajib Pajak bahkan untuk membayar pajak demi kelangsungan hidup negara. Sosialisasi Perpajakan menurut (Rohmawati dan Rasmini, 2012) adalah kegiatan atau upaya yang dilakukan oleh seorang atau organisasi tertentu yang menginformasikan untuk diketahui oleh umumatau kalangan tertentu.

\section{Pengetahuan Perpajakan}

Dalam Kamus Umum Bahasa Indonesia, pengetahuan adalah informasi yang telah digabungkan dengan pemahaman dan potensi untuk menindak yang lantas melekat dibenak seseorang. Menurut (Hartoyo, 2010), pengetahuan teknis perpajakan adalah suatu hasil tahu seseorang dari proses penginderaan terhadap suatu objek tertentu yang berkaitan dengan teknis perpajakan.

\section{Kepatuhan Wajib Pajak}

Indonesia menerapkan sistem self assessment dimana kepatuhan terhadap kewajiban perpajakan menjadikannya aspek yang sangat penting. Wajib Pajak bertanggung jawab untuk memenuhi semua kewajiban perpajakan secara akurat dan tepat waktu. Sedangkan menurut Muliari dan Setiawan (2011), Kepatuhan Wajib Pajak adalah suatu keadaan dimana wajib pajak memenuhi semua kewajiban perpajakan dan melaksanakan hak perpajakannya, maka konteks kepatuhan dalam penelitian ini yaitu wajib pajak berusaha untuk mematuhi peraturan hukum perpajakan yang berlaku, baik dalam memenuhi kewajiban ataupun melaksanakan hak perpajakannya.

\section{Kerangka Konseptual}

Kerangka konseptual merupakan desain penelitian yang berfungsi sebagai penuntun unuk memudahkan memahami alur berpikir dalam penelitian ini. 


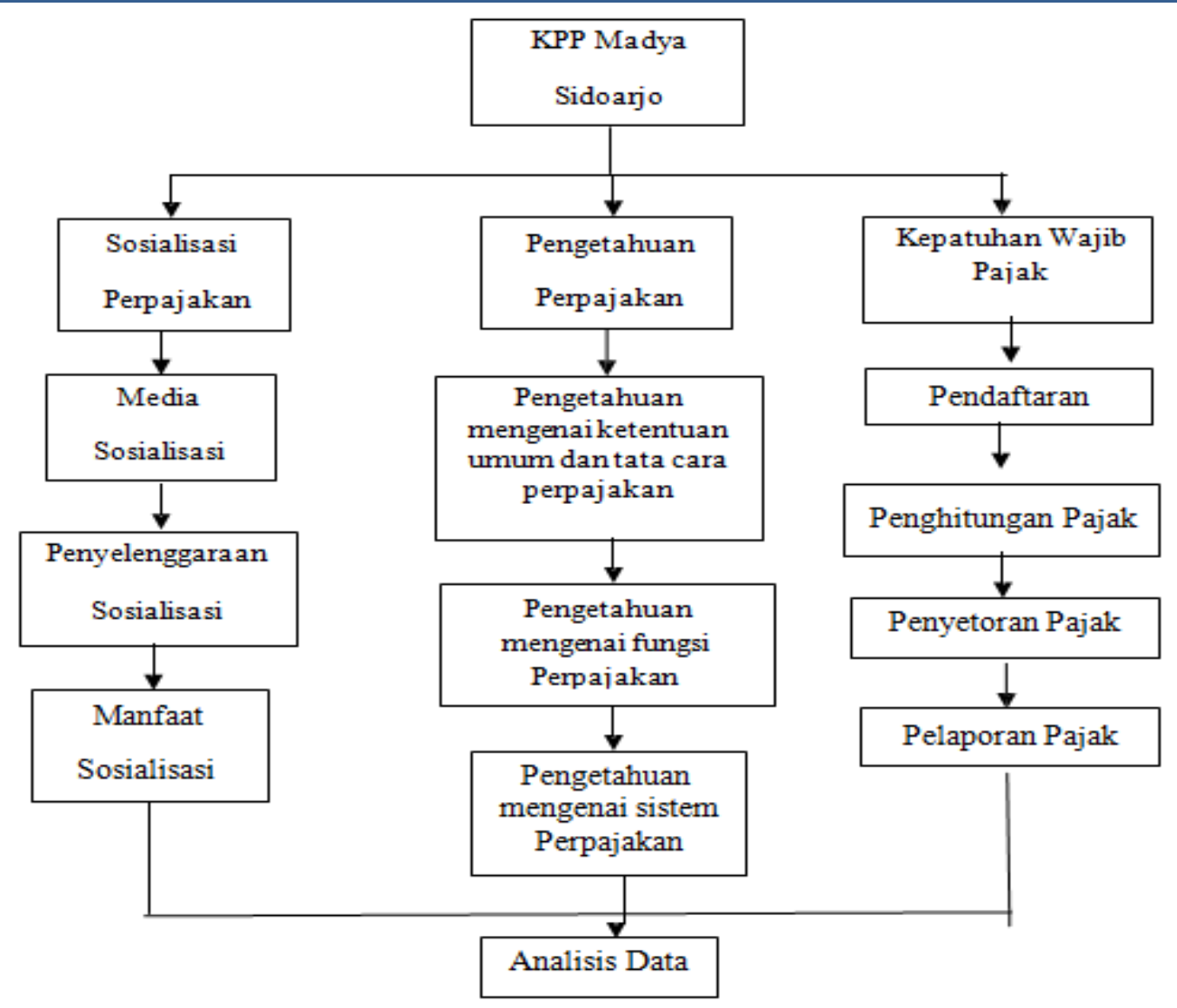

Gambar 1. Kerangka Konseptual

\section{METODE PENELITIAN}

\section{Lokasi Penelitian}

Lokasi penelitian yaitu berada di Kantor Pelayanan Pajak Madya Sidoarjo Jl. Raya Bandara Juanda No. 37, Semambung, Kec. Gedangan, Kab. Sidoarjo.

\section{Pendekatan Penelitian}

Penelitian ini menggunakan pendekatan kualitatif dengan jenis penelitian deskriptif.

\section{Metode Pengumpulan Data}

Metode pengumpulan data dalam penelitian ini memiliki 3 tahap yaitu :

a. Observasi

Menurut Sutrisno Hadi dalam (Sugiyono, 2015) observasi merupakan kegiatan pemuatan penelitian terhadap suatu objek. Dilihat pada proses pengumpulan data, observasi dibedakan menjadi partisipan dan nonpartisipan. Dalam penelitian ini, observasi hal yang diteliti adalah memperoleh data-data informasi terkait dengan pelaksanaan sosialisasi pajak yang diadakan KPP Madya Sidoarjo.

b. Wawancara

Menurut Esterberg dalam (Sugiyono, 2013), wawancara merupakan pertemuan dua orang untuk bertukar informasi dan ide melalui tanya jawab, 
sehingga dapat dikontruksikan makna dalam suatu topik tertentu. Dalam penelitian ini, metode wawancara yang digunakan peneliti adalah wawancara langsung dengan bagian pelayanan pajak KPP Madya Sidoarjo menggunakan pedoman wawancara serta memperoleh keterangan yang terkait dengan penelitian.

c. Dokumentasi

Menurut (Sugiyono, 2015), dokumentasi adalah suatu cara yang digunakan untuk memperoleh data dan informasi dalam bentuk buku, arsip, dokumen, tulisan angka, dan gambar yang berupa laporan serta keterangan yang dapat mendukung penelitian. Dalam penelitian ini, dokumen merupakan pelengkap untuk penelitian kualitatif. Teknik yang dapat diambil berupa data dan dokumentasi yang berasal dari KPP Madya Sidoarjo.

\section{Analisis Data}

Menurut (Sugiyono, 2015), analisis data dapat dibedakan menjadi 3 (tiga) macam, yaitu sebagai berikut:

a. Reduksi Data (Data Reduction)

Reduksi data adalah proses merangkum, memilah-milah data dikarenakan data dari lapangan yang banyak, mencari hal-hal yang penting, mencari inti dari hasil data. Dalam penelitian ini, peneliti melakukan penelitian yang mendalam agar mendapatkan data yang rinci dan akurat.

b. Penyajian Data

Pada tahap ini, data dapat disajikan dengan berbagai bentuk seperti tabel, grafik, chart, dan lainnya. Penyajian data ini bertujuan untuk memudahkan peneliti dapat memahami permasalahan yang ada dan merencanakan apa yang akan dilakukan selanjutnya.

c. Penggambaran Kesimpulan

Setelah melakukan tahap-tahap diatas, peneliti dapat menarik kesimpulan terhadap masalah yang diteliti. Mengambil kesimpulan dari hasil yang sudah diteliti oleh peneliti sehingga memudahkan peneliti untuk mencari solusi untuk permasalahan yang ada dan dapat menarik kesimpulan.

\section{HASIL ANALISIS DAN PEMBAHASAN \\ Jumlah WP Badan pada KPP Madya Sidoarjo}

Tabel 1 dapat disebutkan bahwa jumlah Wajib Pajak Badan yang terdaftar mengalami penurunan yang signifikan dari tahun 2018-2020 yang menyebabkan Wajib Pajak Lapor dari tahun 2018-2020 juga turut menurun. Penurunan jumlah Wajib Pajak Badan di KPP Madya Sidoarjo biasanya disebabkan pertumbuhan setoran pajak badan dari beberapa tahun sebelumnya dan sudah tidak memasuki kriteria untuk terdaftar di KPP Madya Sidoarjo berdasarkan ketentuan Direktorat Jenderal Pajak.

\section{Data Realisasi Pelaksanaan Sosialisasi Perpajakan Pada KPP Madya Sidaorjo tahun 2018-2020}

Dari data pelaksanaan sosialisasi yang terdapat pada Tabel 2, dapat disebutkan bahwa Wajib Pajak maupun Calon Wajib Pajak yang mengikuti pelaksanaan tahun 2018-2020 signifikan karena realisasi dari pelaksanaan mencapai target bahkan beberapa penyuluhan melebihi target yang telah ditetapkan. Pada tahun 
2018, penyuluhan yang dilakukan pada KPP Madya Sidoarjo tidak hanya kepada Wajib Pajak melainkan kepada Calon Wajib Pajak juga. Realisasi pelaksanaan pada tahun 2018 dapat dikatakan efektif karena mencapai target bahkan pada pelaksanaan penyuluhan pada WP OP dan Badan capaian melebihi target yang dicantumkan pada rencana kerja. Pada tahun 2019, target penyuluhan yang dilakukan pada KPP Madya Sidoarjo sama seperti tahun sebelumnya yaitu kepada Wajib Pajak dan Calon Wajib Pajak. Realisasi pelaksaan sosialisasi pada tahun 2019 dapat dikatakan efektif karena mencapai target bahkan pada pelaksanaan penyuluhan pada WP OP dan Badan capaian melebihi target yang dicantumkan pada rencana kerja. Akan tetapi pada tahun 2020, target penyuluhan sosialisasi hanya kepada Wajib Pajak. Realisasi pelaksanaan sosialisasi pada tahun 2020 dapat dikatakan sangat efektif karena melebihi target yang sudah ditetapkan pada rencana kerja penyuluhan. Hal ini disebabkan karena Wajib Pajak yang patuh akan semua ketetapan yang ada di KPP Madya Sidoarjo.

Tabel 1

Data WP Badan Lapor Tepat Waktu dan Tidak Tepat Waktu Tahun 20182020

\begin{tabular}{|c|c|c|c|c|c|c|c|}
\hline \multirow[b]{2}{*}{ Tahun } & \multirow[b]{2}{*}{$\begin{array}{c}\text { Jumlah WP } \\
\text { Badan Wajib }\end{array}$} & \multicolumn{2}{|c|}{ WP Lapor } & \multirow[b]{2}{*}{ Lapor } & \multirow[b]{2}{*}{$\begin{array}{l}\text { Tidak } \\
\text { Lapor }\end{array}$} & \multirow[b]{2}{*}{ Tepat Waktu } & \multirow{2}{*}{$\begin{array}{l}\text { Tidak } \\
\text { Tepat } \\
\text { Waktu }\end{array}$} \\
\hline & & Teapt Waktu & $\begin{array}{c}\text { Tidak } \\
\text { Tepat } \\
\text { Waktu }\end{array}$ & & & & \\
\hline 2018 & 1054 & 1048 & 4 & 1052 & 2 & $99,81 \%$ & $0,91 \%$ \\
\hline 2019 & 864 & 859 & 3 & 862 & 2 & $99,77 \%$ & $0,23 \%$ \\
\hline 2020 & 780 & 778 & 1 & 779 & 1 & $99,87 \%$ & $0,13 \%$ \\
\hline
\end{tabular}

Sumber: Seksi Pengolahan Data dan Informasi (PDI) (2021)

Tabel 2

Realisasi Pelaksanaan Penyuluhan Tahun 2018-2020 KPP Madya Sidoarjo

\begin{tabular}{|c|c|c|c|c|c|c|c|}
\hline Tahun & Tema/Topik & Kegiatan & $\begin{array}{c}\text { Target } \\
\text { Penyuluhan }\end{array}$ & $\begin{array}{c}\text { Rencana } \\
\text { Total }\end{array}$ & Realisasi & Capaian & Jumlah Peserta \\
\hline 2018 & $\begin{array}{c}\text { Penyuluhan Kepada } \\
\text { Calon WP Masa } \\
\text { Depan }\end{array}$ & $\begin{array}{c}\text { Pajak } \\
\text { Mengajar }\end{array}$ & $\begin{array}{l}\text { Pelajar dan } \\
\text { Mahasiswa }\end{array}$ & 3 & 3 & $100 \%$ & 292 \\
\hline 2018 & $\begin{array}{c}\text { Penyuluhan } \\
\text { Kepada WP OP } \\
\text { Pegawai dan WP } \\
\text { Badan }\end{array}$ & $\begin{array}{l}\text { Kelas Pajak } \\
\text { dan Seminar }\end{array}$ & $\begin{array}{l}\text { WP OP Pegawai } \\
\text { dan WP Badan }\end{array}$ & 20 & 56 & $280 \%$ & 3800 \\
\hline 2019 & $\begin{array}{l}\text { Penyuluhan } \\
\text { Kepada Calon WP } \\
\text { Masa Depan }\end{array}$ & $\begin{array}{c}\text { Pajak } \\
\text { Mengajar }\end{array}$ & SD-SMA & 3 & 3 & $100 \%$ & 266 \\
\hline 2019 & $\begin{array}{c}\text { Penyuluhan } \\
\text { Kepada WP OP } \\
\text { Pegawai dan WP } \\
\text { Badan }\end{array}$ & $\begin{array}{c}\text { Kelas Pajak } \\
\text { dan Seminar }\end{array}$ & $\begin{array}{l}\text { WP OP Pegawai } \\
\text { dan WP Badan }\end{array}$ & 20 & 91 & $455 \%$ & 8518 \\
\hline 2020 & $\begin{array}{l}\text { Meningkatkan } \\
\text { Pengetahuan dan } \\
\text { Keterampilan } \\
\text { Perpajakan }\end{array}$ & $\begin{array}{c}\text { Tax } \\
\text { Gathering, } \\
\text { One on One, } \\
\text { Seminar, dan } \\
\text { Kelas Pajak }\end{array}$ & $\begin{array}{c}\text { WP OP } \\
\text { Karyawan } \\
\text { Swasta dan WP } \\
\text { Tertentu dengan } \\
\text { tujuan } \\
\text { peningkatan } \\
\text { Kepatuhan dan } \\
\text { Penerimaan }\end{array}$ & 20 & 61 & $305 \%$ & 1564 \\
\hline
\end{tabular}

Sumber: Seksi Pengolahan Data dan Informasi (PDI) (2021) 
Terkait data pelaksanaan sosialisasi KPP Madya pada tahun 2018-2020, Wajib Pajak Badan yang mengikuti penyuluhan pada tahun 2018-2020 efektif signifikan karena selama 3 (tiga) tahun berturut-turut Wajib Pajak dan Calon Wajib Pajak yang mengikuti penyuluhan tidak menurun. Akan tetapi, pada tahun 2018 dan 2019, KPP Madya Sidoarjo mengadakan penyuluhan kepada Calon WP Baru yang bertujuan untuk meningkatkan pemahaman terkait pengetahuan perpajakan (Tabel 2).

\section{Efektivitas Kegiatan Sosialisasi Perpajakan Pada KPP Madya Sidoarjo}

Menurut (Beni, 2016), Efektivitas adalah hubungan antara output dan tujuan atau dapat juga dikatakan merupakan ukuran seberapa jauh tingkat output, kebijakan dan prosedur dari organisasi. Efektivitas dapat dijelaskan sebagai proses pencapaian tujuan yang telah ditentukan sebelumnya. Hal yang perlu diperhatikan dalam penelitian ini adalah realisasi dan target pada pelaksanaan sosialisasi KPP Madya Sidoarjo tahun 2018-2020. Berikut ini capaian pelaksanaan sosialisasi pajak yang berupa penyuluhan pada periode tahun 2018-2020 yang dapat dijelaskan pada Tabel 3.

Berdasarkan tabel 4.5 , realisasi kegiatan sosialisasi perpajakan pada periode tahun 2018-2020 mencapai target yang ditetapkan. Pada tahun 2018 melampaui target sebesar 120\%, pada tahun 2019 dan 2020 mencapai target yang ditetapkan yaitu masingmasing sebesar 50\% dan 100\%. Artinya, mayoritas Wajib Pajak yang mengikuti sosialisasi perpajakan berupa penyuluhan memenuhi undangan yang disampaikan oleh KPP Madya Sidoarjo.

Sosialisasi Perpajakan di KPP Madya Sidoarjo merupakan tanggung jawab dan wewenang dari Seksi Pelayanan. Sosialisasi Pajak dilaksanakan agar memberikan pengetahuan dan pemahaman untuk Wajib Pajak yang belum paham akan pentingnya membayar pajak. Selain itu, Wajib Pajak diberikan sosialisasi perpajakan agar meningkatkan kepatuhan terhadap pajak.

Perhitungan tingkat efektivitas sosialisasi perpajakan berdasarkan data jumlah realisasi kegiatan penyuluhan terhadap total rencana kerja kegiatan penyuluhan tahun 2018-2020, dapat dijabarkan sebagai berikut:

1. Efektivitas tahun 2018

$$
=\{(\text { rasio kegiatan penyuluhan }) \times 100 \%\} \times 50 \%+\{\text { (rasio perubahan perilaku }) \times 50 \%\}
$$$$
=\{(20 / 20 \times 100) \times 50 \%)+50 \%\}
$$$$
=100 \%
$$

2. Efektivitas tahun 2019 $=\{($ rasio kegiatan penyuluhan $) \times 100 \%\} \times 50 \%+\{$ (rasio perubahan perilaku $) \times 50 \%\}$

$$
=\{(20 / 20 \times 100) \times 50 \%)+50 \%\}
$$$$
=100 \%
$$

3. Efektivitas tahun 2020

$=\{($ rasio kegiatan penyuluhan $) \times 100 \%\} \times 50 \%+\{$ (rasio perubahan perilaku $) \times 50 \%\}$

$=\{(20 / 20 \times 100) \times 50 \%)+50 \%\}$

$$
=100 \%
$$

Pada perhitungan diatas menunjukkan bahwa pada tingkat sosialisasi perpajakan pada tahun 2018-2020 efektif dengan presentase $100 \%$.

Keterangan:

a. Rasio kegiatan penyuluhan merupakan perbandingan antara jumlah realisasi kegiatan penyuluhan terhadap total rencana kegiatan penyuluhan. Realisasi 
kegiatan penyuluhan yang dapat diakui sebagai realisasi adalah maksimal sebesar rencana kegiatan penyuluhan.

b. Kanwil DJP Wajib Pajak Besar, Kanwil DJP Khusus dan KPP selain KPP Pratama yang sesuai basis data tidak terdapat Wajib Pajak yang memerlukan untuk diubah perilakunya, maka IKU ini diukur hanya dari presentase realisasi kegiatan penyuluhan terhadap rencana kegiatan penyuluhan yaitu sebesar bobot $50 \%$ dan dianggap sudah efektif.

\section{Wawancara terkait Pengetahuan Perpajakan pada KPP Madya Sidoarjo}

Pengetahuan Perpajakan adalah adalah kemampuan yang dimiliki oleh wajib pajak mengenai hak dan kewajiban sebagai wajib pajak sehingga wajib pajak mampu menghindari sanksi perpajakan (Rahayu, 2017).

Efektivitas pengetahuan perpajakan ini dapat dilihat dari sudut pandang petugas pajak yang ada di KPP Madya Sidoarjo dikarenakan Wajib Pajak Badan yang ada di KPP Madya Sidoarjo tidak ikut berpatisipasi dalam penelitian ini karena identitas yang harus dirahasiakan sesuai peraturan yang ada di KPP Madya. Selanjutnya, untuk mengetahui efektivitas pengetahuan perpajakan, peneliti melakukan wawancara kepada subjek penelitian yaitu Bapak Ari Eko Hartoyo selaku Kepala Seksi Pelayanan sesuai dengan pedoman wawancara yang telah ditentukan (Tabel 5).

Berdasarkan penuturan Bapak Ari selaku Kepala Seksi Pelayanan, pengetahuan perpajakan secara umum tentang pengetahuan ketentuan umum dan tata cara perpajakan dengan item pertanyaan yaitu NPWP, Wajib Pajak yang terdaftar di KPP Madya otomatis sudah memiliki NPWP karena sebelum dialihkan ke KPP Madya Sidoarjo, pihak Wajib Pajak biasanya bukan Wajib Pajak baru dan sudah tersdaftar di KPP Pratama yang tersebar di Kanwil II. Selanjutnya, fungsi perpajakan yang ada di KPP Madya Sidoarjo diterapkan sesuai dengan Standar Operasional Prosuder (SOP). Jadi, semua kantor yang ada di KPP Madya Sidoarjo sudah menerapk an fungsi perpajakan dengan baik berdasarkan SOP yang berlaku. Terakhir, untuk sistem perpajakan yaitu Self Assesment System. Sistem perpajakan Self Assesment System baik untuk Wajib Pajak karena Wajib Pajak bisa menentukan sendiri besarnya pajak yang terutang dan penerapan Self Assesment System diimbangi dengan sosialisasi dalam bentuk penyuluhan, bimbingan, dan konsultasi di Kantor Pajak. Selain itu, jika Wajib Pajak kurang memahami materi yang disampaikan oleh petugas pajak bisa bertanya kepada job desk yang sudah tercantum sesuai tugas masing-masing (Tabel 5).

Tabel 3

Realisasi dan Target Pelaksanaan Sosialisasi Perpajakan tahun 2018-2020 KPP Madya Sidoarjo

\begin{tabular}{ccc}
\hline Tahun & Target & Realisasi \\
\hline 2018 & $50,00 \%$ & $120,00 \%$ \\
2019 & $50,00 \%$ & $50,00 \%$ \\
2020 & $100,00 \%$ & $100,00 \%$ \\
\hline
\end{tabular}

Sumber: Data Diolah (2021) 
Tabel 4

Tingkat Efektivitas Sosialisasi Perpajakan pada tahun 2018-2020 KPP

Madya Sidoarjo

\begin{tabular}{cccc}
\hline Tahun & Realisasi kegiatan & Total rencana kerja & Efektivitas \\
\hline 2018 & 56 & 20 & $100 \%$ \\
2019 & 864 & 20 & $100 \%$ \\
2020 & 780 & 20 & $100 \%$ \\
\hline
\end{tabular}

Sumber: Data Diolah (2021)

Tabel 5

Daftar Pertanyaan terkait Pengetahuan Perpajakan KPP Madya Sidoarjo

\begin{tabular}{|c|c|c|}
\hline Indikator & Instrumen & Daftar Pernyataan \\
\hline \multirow{3}{*}{$\begin{array}{l}\text { Pengetahuan } \\
\text { Perpajakan }\end{array}$} & $\begin{array}{l}\text { Pengetahuan mengenai } \\
\text { ketentuan umum dan tata cara } \\
\text { perpajakan (Khasanah, 2014) }\end{array}$ & $\begin{array}{l}\text { 1. Apa pengaruh } \\
\text { kepemilikan NPWP } \\
\text { terhadap kepatuhan } \\
\text { wajib pajak yang ada di } \\
\text { KPP Madya Sidoarjo? } \\
\text { 2. Tanggal berapa terakhir } \\
\text { melapor dan menyetor } \\
\text { pajak? }\end{array}$ \\
\hline & $\begin{array}{l}\text { Pengetahuan mengenai fungsi } \\
\text { perpajakan (Khasanah, 2014) }\end{array}$ & $\begin{array}{l}\text { 1. Apakah fungsi } \\
\text { perpajakan di Indonesia } \\
\text { sudah ditetapkan dengan } \\
\text { baik? }\end{array}$ \\
\hline & $\begin{array}{l}\text { Pengetahuan mengenai sistem } \\
\text { perpajakan di Indonesia } \\
\text { (Khasanah, 2014) }\end{array}$ & $\begin{array}{l}\text { 1. Apakah pengaruh self } \\
\text { assesment system } \\
\text { terhadap kepatuhan } \\
\text { wajib pajak yang ada di } \\
\text { KPP Madya Sidoarjo? } \\
\text { 2. Bagaimana pendapat } \\
\text { anda tentang sistem ini? }\end{array}$ \\
\hline
\end{tabular}

Sumber: Data Diolah (2021)

\section{Tabel 6}

Data Wajib Pajak Terdaftar dan Lapor tahun 2018-2020 KPP Madya Sidoarjo

\begin{tabular}{ccc}
\hline Tahun & Jumlah Wajib Pajak Terdaftar & Jumlah Wajib Pajak Lapor \\
\hline 2018 & 1054 & 1052 \\
2019 & 864 & 862 \\
2020 & 780 & 779 \\
\hline
\end{tabular}

Sumber: Data Diolah (2021)

\section{Analisis Efektivitas Kepatuhan Wajib Pajak Pada KPP Madya Sidoarjo}

Kepatuhan Wajib Pajak adalah suatu tindakan taat dan paham akan ketertiban pembayaran maupun pelaporan kewajiban perpajakan masa dan tahunan berupa beberapa kumpulan orang dan/ atau modal, serta Wajib Pajak yang menjalankan usaha sesuai dengan peraturan perpajakan yang berlaku. Kepatuhan Wajib Pajak di KPP Madya Sidoarjo merupakan output atau hasil yang diperoleh dari adanya sosialisasi pajak dan pengetahuan perpajakan. Indikator untuk mengetahui 
efektivitas kepatuan wajib pajak ini memiliki 4 (empat) instrumen yaitu pendaftaran, penghitungan pajak, penyetoran pajak, pelaporan pajak. Berikut ini capaian kepatuhan wajib pajak pada periode tahun 2018-2020 yang dapat dijelaskan pada Tabel 6.

Berdasarkan Tabel 6 dapat dijelaskan bahwa tahun 2018 jumlah WP terdaftar pada KPP Madya Sidoarjo sebesar 1054 WP, pada tahun 2019 menunjukkan sebesar 864 WP, sedangkan pada tahun 2020 berjumlah 780 WP. Angka ini terus menurun per tahunnya karena disebabkan pertumbuhan setoran pajak badan yang terus menurun per 3 tahun dan berdasarkan keputusan Direktorat Jenderal Pajak.

Perhitungan tingkat efektivitas kepatuhan wajib pajak berdasarkan data Wajib Pajak terdaftar dan data Wajib Pajak lapor tahun 2018-2020, dapat dijabarkan sebagai berikut :

1. Tingkat efektivitas kepatuhan Wajib Pajak pada tahun 2018

$$
\begin{aligned}
\text { Efektivitas tahun } 2018 & =\frac{\text { Jumlah Wajib Pajak Lapor tahun } 2018}{\text { Jumlah Wajib Pajak Terdaftar tahun } 2018} \times 100 \% \\
& =\frac{1052}{1054} \times 100 \% \\
& =99,81 \%
\end{aligned}
$$

Pada perhitungan diatas menunjukkan bahwa pada tingkat kepatuhan wajib pajak pada tahun 2018 cukup tinggi dengan presentase $99,87 \%$.

2. Tingkat efektivitas Kepatuhan Wajib Pajak pada Tahun 2019

$$
\begin{aligned}
\text { Efektivitas tahun } 2019 & =\frac{\text { Jumlah Wajib Pajak Lapor tahun } 2019}{\text { Jumlah Wajib Pajak Terdaftar tahun } 2019} \times 100 \% \\
& =\frac{862}{864} \times 100 \% \\
& =99,76 \%
\end{aligned}
$$

Pada perhitungan diatas menunjukkan bahwa pada tingkat kepatuhan wajib pajak pada tahun 2019 cukup tinggi dengan presentase 99,76\%.

3. Tingkat efektivitas Kepatuhan Wajib Pajak pada Tahun 2020

$$
\begin{aligned}
\text { Efektivitas tahun } 2020 & =\frac{\text { Jumlah Wajib Pajak Lapor tahun } 2019}{\text { Jumlah Wajib Pajak Terdaftar tahun } 2019} \times 100 \% \\
& =\frac{779}{780} \times 100 \% \\
& =99,87 \%
\end{aligned}
$$

Pada perhitungan diatas menunjukkan bahwa pada tingkat kepatuhan wajib pajak pada tahun 2020 cukup tinggi dengan presentase $99,87 \%$.

\section{SIMPULAN}

Berdasarkan hasil penelitan yang berjudul "Analisis Efektivitas Sosialisasi Perpajakan dan Pengetahuan Perpajakan Dalam Rangka Meningkatkan Kepatuhan Wajib Pajak Pada KPP Madya Sidoarjo" dapat disimpulkan sebagai berikut: (1) Kegiatan sosialisasi perpajakan termasuk kategori efektif karena Wajib Pajak Badan yang terdaftar di KPP Madya Sidoarjo sudah mengikuti sosialisasi atau penyuluhan yang dilakukan oleh petugas pajak. Manfaat yang didapat setelah mengikuti sosialisasi perpajakan adalah pengetahuan perpajakan yang berupa peraturan pajak terbaru setiap penyuluhan dan bisa memotivasi mereka untuk patuh terhadap pajak. (2) Pengetahuan perpajakan yang didapatkan saat sosialisasi pajak di KPP Madya Sidoarjo sudah memenuhi indikator pengetahuan Wajib Pajak oleh Widyati dan Nurlis (2010). Mayoritas Wajib Pajak Badan 
yang ada di KPP Madya Sidoarjo sudah memiliki NPWP, memahami terkait sistem pemungutan yaitu Self Assesment System, dan memahami fungsi perpajakan sudah diterapkan dengan baik di KPP Madya Sidoarjo. (3) Kepatuhan Wajib Pajak memberikan hasil bahwa Kepatuhan Wajib Pajak pada KPP Madya Sidoarjo cukup tinggi. Hal ini dikarenakan mayoritas Wajib Pajak Badan memenuhi 2 (dua) indikator yang menjadi indikator kepatuhan Wajib Pajak yaitu sesuai dengan Peraturan Menteri Keuangan Nomor 74/PMK.03/2012. 2 indikator kepatuhan Wajib Pajak tersebut adalah tepat waktu dalam menyampaikan Surat Pemberitahuan (SPT) Pajak dan tidak mempunyai tunggakan untuk semua jenis pajak. Saran untuk Wajib Pajak yang ada di KPP Madya yang diberikan peneliti adalah supaya lebih aktif dalam mengikuti sosialisasi perpajakan dan memahami pengetahuan yang disampaikan oleh pemateri. Karena sangat penting dalam memahami pengetahuan yang didapat sosialisasi, banyak pengetahuan baru dan peraturan baru yang dikeluarkan oleh Menteri Keuangan dan Direktorat Jenderal Pajak. Saran untuk petugas pajak yang diberikan peneliti adalah supaya petugas pajak lebih efektif dalam mengadakan sosialisasi pajak kepada Wajib Pajak karena merupakan sebuah kewajiban dalam memberikan sosialisasi. Peneliti menyarankan dalam memberikan sosialisasi pajak, petugas pajak lebih baik turun langsung ke lapangan dengan mendatangi setiap Wajib Pajak Badan yang terdaftar di KPP Madya Sidoarjo. Saran untuk peneliti selanjutnya yang diberikan peneliti adalah supaya menambah subjek penelitian dan memperbanyak data yang berkaitan dengan penelitian agar hasil penelitian lebih beragam. Selain itu, peneliti berharap peneliti selanjutnya dapat melakukan penelitian dengan periode waktu yang lebih lama akan mendapatakan hasil yang lebih akurat dan maksimal.

\section{DAFTAR PUSTAKA}

$A P B N$ KITA. (n.d.). Retrieved from Direktorat Jenderal Perimbangan Keuangan: www.djkp.kemenkeu.go.id.

Direktorat Jenderal Pajak. (2018, Mei 31). Pajak dan Pembangunan Nasional. Retrieved from www.pajak.go.id/artikel/pajak-dan-pembangunan-nasional.

Hartoyo. (2010). Analisis Faktor yang Mempengaruhi Kepatuhan Wajib Pajak Orang Pribadi Memiliki Nomor Pokok Wajib Pajak (NPWP). Ekonomi.

Mustikasari. (2007). Kajian Empiris tentang Kepatuhan Wajib Pajak Badan di Perusahaan Industri Pengolahan di Surabaya. Ekonomi.

Pakei, Beni. (2016). Konsep dan Analisis (Efektivitas Pengelolaan Keuangan Daerah di Era Otonomi Daerah). Jayapura: Taushia.

Rahayu, S. K. (2017). Perpajakan Konsep dan Aspek Formal. Bandung: Rekayasa Sains. Resmi, S. (2014). Perpajakan Teori dan Kasus. Jakarta: Salemba Empat.

RI, M. K. (2020). APBN KITA KINERJA DAN FAKTA Edisi Desember 2020. Jakarta: Menteri Keuangan RI.

Rizky, M. N. (2019). Pemanfaatan Teknologi Informasi, Sosialisasi Perpajakan, dan Pengetahuan Perpajakan Terhadap Kepatuhan Wajib Pajak. Ekonomi dan Bisnis. Robbins, S. P. (1996). Perilaku Organisasi Edisi ke 7. Jakarta: Prehallindo. 
Ekobis: Jurnal Ekonomi \& Bisnis

Vol. 2 No. 12021

Nur Lailiyatul Inayah dkk., Analisis Efektivitas Sosialisasi

Rohmawati, A. N. (2012). Pengaruh Kesadaran, Penyuluhan, Pelayanan dan Sanksi Perpajakan pada Kepatuhan Wajib Pajak Orang Pribadi. Ekonomi.

Rohmawati, R. d. (2012). Pengaruh Kesadaran, Penyuluhan, Pelayanan, dan Sanksi

Perpajakan Pada Kepatuhan Wajib Pajak Orang Pribadi. Ekonomi.

Sugiyono. (2005). Metode Penelitian Administrasi. Bandung: Alfabeta.

Sugiyono. (2013). Statistika untuk Penelitian. Bandung : Alfabeta.

Sugiyono. (2015). Metode Penelitian Pendidikan (Metode Pendekatan Kuantitatif, Kualitatif, dan $R \& D)$. Bandung: Alfabeta.

Surat Edaran Direktorat Jenderal Pajak Nomor : SE-24/PJ/2019 Tentang Implementasi Compliance Risk Management Dalam Kegiatan Ekstensifikasi, Pengawasan, Pemeriksaan, dan Penagihan Direktorat Jenderal Pajak. (n.d.).

Winterungan, O. L. (2013). Sosialisasi Perpajakan, Pelayanan Fiskus, dan Sanksi Perpajakan Terhadap Kepatuhan WPOP di KPP Manado dan KPP Bitung. Ekonomi dan Bisnis. 